\title{
Moho depth of the European Plate from teleseismic receiver functions
}

\author{
Marek Grad • Timo Tiira
}

Received: 29 January 2011 / Accepted: 14 September 2011 /Published online: 29 September 2011

(C) The Author(s) 2011. This article is published with open access at Springerlink.com

\begin{abstract}
Crustal structure and the Moho depth are exceptionally well known beneath Europe. The first digital, high-resolution map of the Moho depth for the whole European Plate was compiled in 2007 and recently published in Geophysical Journal International. In the past few years, considerable developments have taken place in the receiver function techniques. Different receiver function techniques provide new, independent information, in particular on the $S$-wave velocity distribution in the crust and on the Moho depth. This gives an opportunity to compare the Moho depth from the Moho depth map of the European Plate $\left(H_{\mathrm{MM}}\right)$ and the Moho depth from receiver function studies $\left(H_{\mathrm{RF}}\right)$. Herein, we also compile and analyze the uncertainty of the crustal thickness determinations data obtained with receiver function analysis. The uncertainty is found to be $\pm 2 \mathrm{~km}$ for 20 -km-thick crust and about $\pm 4 \mathrm{~km}$ for 60 km-thick crust. Comparison of the Moho depths shows an approximately linear trend between $H_{\mathrm{RF}}$ and $H_{\mathrm{MM}}$. For the Moho depth of $30-40 \mathrm{~km}$, the
\end{abstract}

\footnotetext{
M. Grad $(\bowtie)$

Institute of Geophysics, Faculty of Physics,

University of Warsaw,

Pasteura 7,

02-093 Warsaw, Poland

e-mail: mgrad@mimuw.edu.pl

T. Tiira

Institute of Seismology, University of Helsinki,

P.O. Box 68, 00014 Helsinki, Finland

e-mail: timo.tiira@helsinki.fi
}

values are approximately equal, while for thin crust, $H_{\mathrm{RF}}$ is about $5 \mathrm{~km}$ shallower than $H_{\mathrm{MM}}$, and for thick crust, it is about $5 \mathrm{~km}$ deeper than $H_{\mathrm{MM}}$. Possible reasons for this, the observed discrepancy between the Moho depths $\mathrm{H}_{\mathrm{MM}}$ and $\mathrm{H}_{\mathrm{RF}}$, are discussed.

Keywords Teleseismic receiver function - Crustal thickness · Moho discontinuity · European Plate

\section{Introduction}

The boundary between crust and upper mantle was discovered by the Croatian seismologist Andrija Mohorovičić, and it is defined as a distinct discontinuity in the seismic wave velocities (Mohorovičić 1910). Studies during the subsequent 100 years showed that this discontinuity was a worldwide phenomenon, and it was named the Mohorovičić discontinuity, Moho, or M-discontinuity. Today, the seismologically defined Earth's crust is understood to be the outer shell of our planet in which the velocity of $P$ waves is less than about $7.6 \mathrm{~km} \mathrm{~s}^{-1}$ and $S$-wave velocity is less than about $4.4 \mathrm{~km} \mathrm{~s}^{-1}$ (e.g., Meissner 1986). In general, $P$ wave velocity in the lower crust is about $7 \mathrm{~km} \mathrm{~s}^{-1}$ and in the uppermost mantle about $8 \mathrm{~km} \mathrm{~s}^{-1}$. Thus, the $P$ wave velocity contrast at the Moho discontinuity is quite large, up to $1-1.5 \mathrm{~km} \mathrm{~s}^{-1}$. $S$-wave velocity in the lower crust is about $4 \mathrm{~km} \mathrm{~s}^{-1}$ and in the uppermost mantle about $4.6 \mathrm{~km} \mathrm{~s}^{-1}$, and the corresponding contrast at the Moho is over $0.5 \mathrm{~km} \mathrm{~s}^{-1}$. This indicates 
a significant change in the elastic parameters, resulting from a significant change in the rock types between crust and uppermost mantle.

Because of its sharp contrast, the Moho can be studied relatively easily using geophysical and, in particular, seismic methods. A large number of such data sets-individual seismic profiles, 3-D models obtained from body and surface waves, results from receiver function studies and regional seismic and/or gravity maps - were compiled for Europe (Grad et al. 2009). This is the first digital, high-resolution map of the Moho depth for the whole European Plate, which extends from the mid-Atlantic ridge in the west to the Ural Mountains in the east, and from the Mediterranean Sea in the south to the Barents Sea and Spitsbergen in the Arctic in the north (Fig. 1). In general, three large domains are visible within the European Plate crust. The oldest Archean and Proterozoic crust has a thickness of $40-60 \mathrm{~km}$, the continental Variscan and Alpine crust has a thickness of $20-40 \mathrm{~km}$, and the youngest oceanic Atlantic area has the Moho depth at 10-20 km.
In the past decades, and in particular in the past few years, considerable developments in the receiver function (RF) techniques have taken place. A large number of new Moho depth (crustal thickness) determinations, beneath permanent broadband seismic stations and temporary arrays used in passive experiments, motivated us to compare the Moho depths $H_{\mathrm{MM}}$ from the Moho depth map of the European Plate (Grad et al. 2009) and the Moho depths $H_{\mathrm{RF}}$ from receiver function analysis.

\section{Receiver function data}

Different RF techniques provide new, independent information on the distribution of seismic velocities in the crust and/or crustal thickness. We analyze a large number of new determinations of crustal thickness beneath permanent broadband seismic stations and temporary arrays used in passive experiments (for location, see Fig. 1). The database of crustal thickness evaluations from receiver function studies comprises

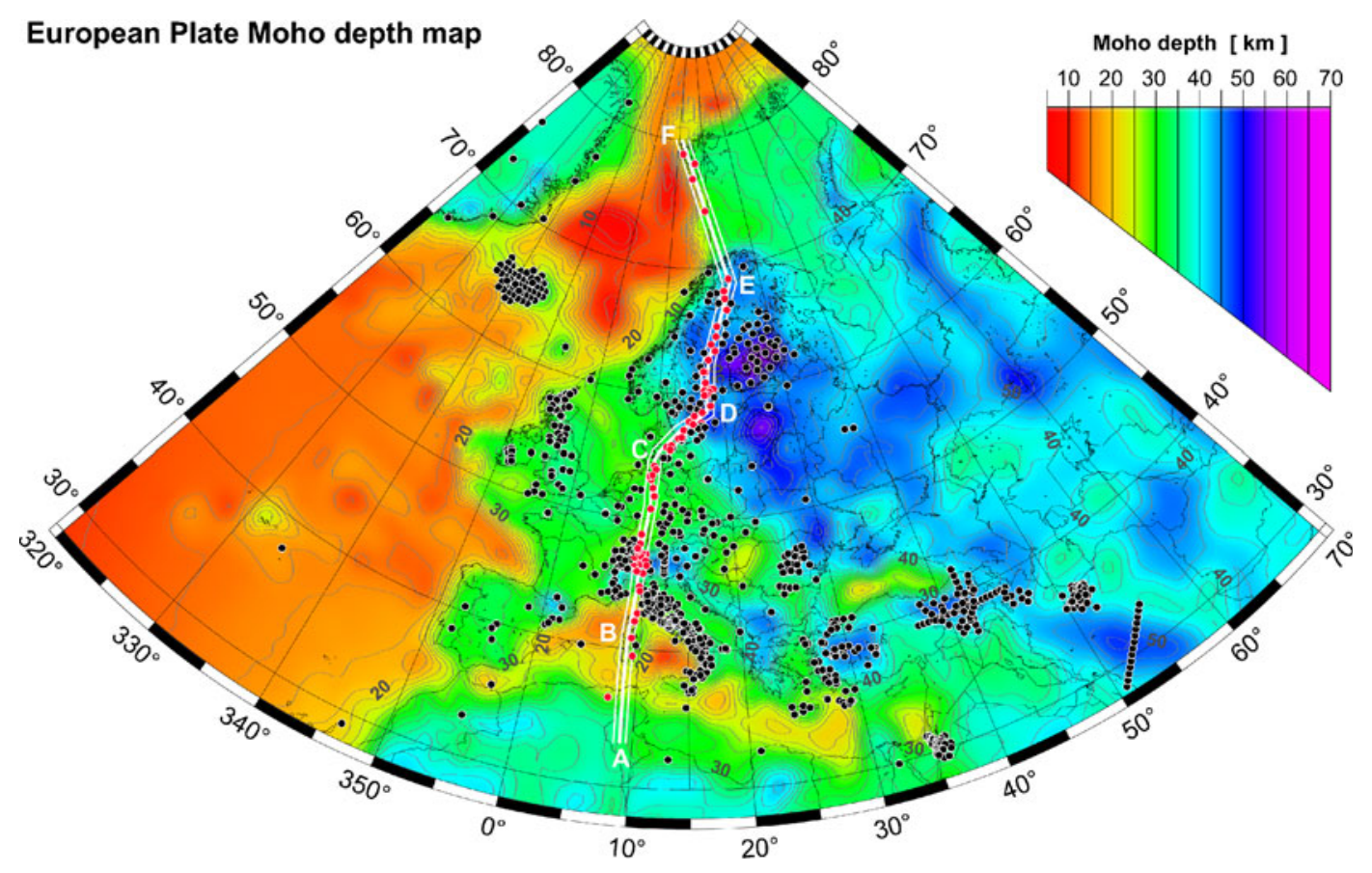

Fig. 1 The Moho depth map of the European Plate (Grad et al. 2009) and spatial coverage by receiver function data used in the present paper (black and red dots). The database on receiver function data comprises more than 40 data sets ( 1,016 points) from permanent seismic stations and temporary arrays used in passive experiments - for references, see Table 1. The map is plotted using Lambert projection. Thick white line $A-F$ shows a transect with a \pm 50 -km-wide corridor limited by white thin lines; stations with receiver function data within this corridor are marked in red and compared with refraction data and the Moho map-for explanation, see Fig. 5 
more than 40 data sets $(1,016$ points with geographic coordinates $\lambda$ and $\phi$, crustal thickness, and topography). The publications used in this analysis are listed in Table 1. As seen in Fig. 1, the coverage of RF data is inhomogeneous. The data cover mostly the continental part of the European Plate, with the largest concentration of data in the Baltic shield, the Alps, and the Apennines. Also Iceland at the Mid-Atlantic ridge has quite good coverage, while only single station data are available from most islands on the oceanic part of the plate. The Moho depth map refers to the sea level, and crustal thickness values from RF were corrected for topography. In some cases, we used original data from published papers. In others, topography was taken from ETOPO1 (Amante and Eakins 2009), which is a 1-arc-min global relief model of the Earth's surface topography and ocean bathymetry. The original data points in geographical coordinates were transformed to $x y$-coordinate system to reduce distortion caused by handling geographic data from different latitudes. Geographical coordinates were changed to $x y$-coordinates with Lambert projection in the scale $1: 10,000,000$ using origin of $59.5^{\circ} \mathrm{N}, 15.0^{\circ} \mathrm{E}$ and standard parallels of $30^{\circ} \mathrm{N}$ and $86^{\circ} \mathrm{N}$. The data points were changed to a $10 \times 10 \mathrm{~km}$ grid using an adjustable tension continuous curvature surface gridding algorithm (Smith and Wessel 1990). Sometimes, $H_{\mathrm{RF}}$ was determined more than once for the same station with different methods or with different data sets. Before gridding, the data were pre-processed to eliminate redundant data and to avoid spatial aliasing. This was done by transforming the original points to $10 \times 10 \mathrm{~km}$ block averages. All coordinate manipulation and plotting were done with The Generic Mapping Tools (GMT, Wessel and Smith 1991, 1998). The Moho depth map compiled from receiver function studies $\left(H_{\mathrm{RF}}\right)$ is shown in Fig. 2.

Some authors give an uncertainty $\left|\Delta H_{\mathrm{RF}}\right|$ for their crustal thickness $H_{\mathrm{RF}}$. These error estimates have been obtained using bootstrapping, data variance, and chisquare-like methods. We analyze the relationship between the crustal thickness and the uncertainty of the crustal thickness for 393 receiver function results. The data and results of analysis are shown in Fig. 3a. The maximum uncertainty is about $8 \mathrm{~km}$, and the uncertainties are mostly concentrated at $1-4 \mathrm{~km}$. In Fig. 3a, a thick line shows the linear dependence fitted to the data:

$$
\left|\Delta H_{\mathrm{RF}}\right|=0.480+0.051 H_{\mathrm{RF}},
$$

where $\Delta H_{\mathrm{RF}}$ and $H_{\mathrm{RF}}$ are in kilometers. About $85 \%$ of the data lie within $2 \mathrm{~km}$ from the fitted line. The uncertainty of the crustal thicknesses is about $\pm 2 \mathrm{~km}$ for 20 -km-thick crust and about $\pm 4 \mathrm{~km}$ for 60 -kmthick crust. In general, the relation (1) shows that the uncertainty of the crustal thicknesses determined using RF is slightly larger than $5 \%$.

Crustal thicknesses from the Moho depth map $\left(H_{\mathrm{MM}}\right)$ were obtained for locations of the receiver function data points. For $H_{\mathrm{RF}}$, the topography was

Table 1 Sources of receiver function data for crustal thickness (Moho depth) used in this paper

\begin{tabular}{ll}
\hline Area & References for receiver function data \\
\hline East European platform & Aleshin et al. (2006), Kortström et al. (2006), Kozlovskaya et al. (2008), Olsson et al. (2008), \\
& Wilde-Piórko et al. (2002) \\
Central Europe & Diehl et al. (2005), Geissler et al. (2008), Hetényi and Bus (2007), Wilde-Piórko et al. \\
& $(2002$, 2005), Zhang and Langston (1995) \\
Western Europe & Di Leo et al. (2009), Julià and Mejía (2004), Landes et al. (2006), Ottemöller and Midzi (2003), \\
& Tomlinson et al. (2006), Zhang and Langston (1995) \\
Mediterranean Sea and Alpine & Bertrand and Deschamps (2000), Kummerow et al. (2004), Li et al. (2003), Lombardi et al. \\
area & (2008), Marone et al. (2003), Mele and Sandvol (2003), Mele et al. (2006), van der Meijde et al. \\
& (2003), Piana Agostinetti and Amato (2009), Zor et al. (2006) \\
Atlantic and polar regions & Foulger and Anderson (2005), Gudmundsson (2003), Harland et al. (2009), Kumar et al. (2007), \\
& Ottemöller and Midzi (2003), Silveira et al. (2010), Wilde-Piórko et al. (2009) \\
European Plate surroundings & Al-Damegh et al. (2005), Angus et al. (2006), Dahl-Jensen et al. (2003), \\
& Doloei and Roberts (2003), Mohsen et al. (2005), Paul et al. (2006), Radjaee et al. (2010), \\
& Saunders et al. (1998), Sodoudi et al. (2009), Taghizadeh-Farahmand et al. (2010), \\
& Tezel et al. (2010), Weber et al. (2004), Zor et al. (2003)
\end{tabular}




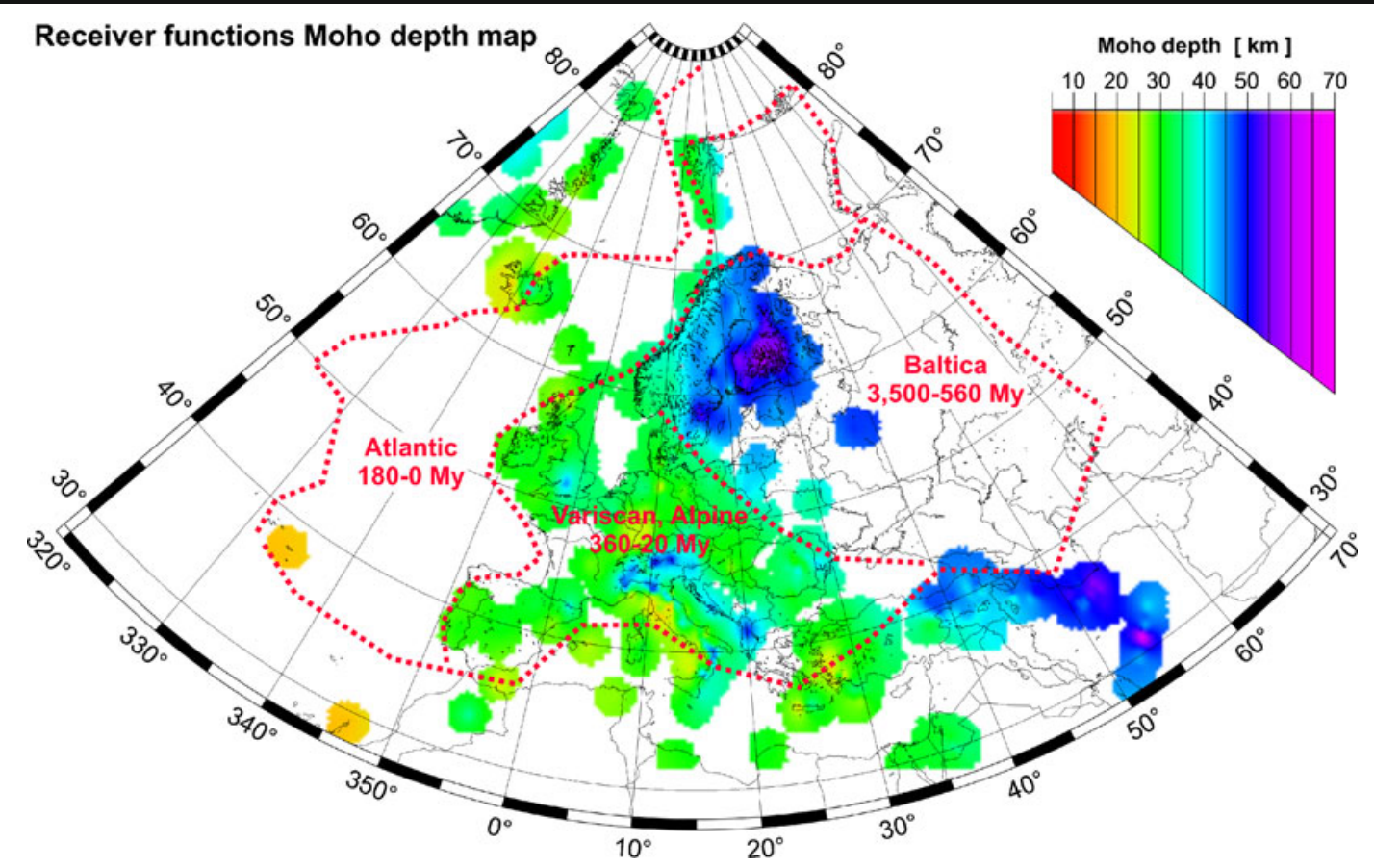

Fig. 2 The Moho depth map from the receiver function data as compiled for this study. For each station, a mask of $140 \mathrm{~km}$ radius was used to plot the Moho depth. The map is plotted using Lambert projection. Red dotted lines mark borders of

taken into consideration. Both depths $H_{\mathrm{RF}}$ and $H_{\mathrm{MM}}$ are in kilometers below sea level. The uncertainty of $H_{\mathrm{MM}}$ was taken from the uncertainty map associated with the Moho map (Grad et al. 2009). The uncertainty of $H_{\mathrm{RF}}$ was taken from the original papers. For the crustal thickness determinations for which uncertainty was not given by the authors, we used statistical relation (1). In the following analysis, the total number of data points is $1,016 . H_{\mathrm{RF}}$ and $H_{\mathrm{MM}}$ depths with error bars are plotted in Fig. $3 \mathrm{~b}$. The Moho depth $H_{\mathrm{RF}}$ covers over $60 \mathrm{~km}$ range. The shallowest Moho $H_{\mathrm{RF}}=7.9 \mathrm{~km}$ is observed for the station BORG, Iceland (Geissler et al. 2008), and the deepest $H_{\mathrm{RF}}=68.5 \mathrm{~km}$ for the Zagros belt (Paul et al. 2006). This comparison shows a linear trend between $H_{\mathrm{RF}}$ and $H_{\mathrm{MM}}$ (both in kilometers):

$H_{\mathrm{MM}}=11.746( \pm 0.644)+0.613( \pm 0.018) H_{\mathrm{RF}}$,

with a standard deviation of $\chi^{2}=1.330$. As seen in Fig. 3b, for the Moho depths of 30-40 km, the values are approximately the same, while for thin crust, the Moho from $R F$ is about $5 \mathrm{~km}$ shallower, and for thick crust, the Moho is about $5 \mathrm{~km}$ deeper. three age groups of the European crust - thin and young oceanic crust of the Atlantic Ocean, the continental crust of the Variscan and the Alpine Europe, and the thickest and oldest crust of the Archean and Proterozoic Baltica

The best coverage of crustal thickness from RF determinations is available for the continental part of the Western and Central Europe. For this area, we made more detailed comparison between the Moho depth estimates from RF studies and from other methods. Figure 4 a shows uncertainty of the crustal thicknesses determined from receiver function analysis $\left|\Delta H_{\mathrm{RF}}\right|$. The difference of $H_{\mathrm{RF}}-H_{\mathrm{MM}}$ is shown in Fig. $4 \mathrm{~b}$. For the most part of the area, the difference is in the order of $\pm 6 \mathrm{~km}$, and the largest difference is observed for the area of Sicily and the Zagros belt.

\section{Discussion of the deviations, uncertainties, and errors}

In this section, we discuss the uncertainties and errors in the Moho depth determinations, as well as possible reasons for the difference between Moho depths $H_{\mathrm{MM}}$ and $H_{\mathrm{RF}}$.

In construction of the Moho depth map for the European Plate (Grad et al. 2009), different types of data were used, and in most cases, the Moho depths 


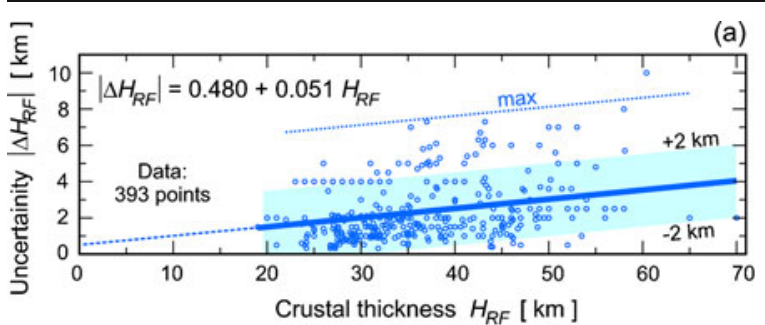

(b)

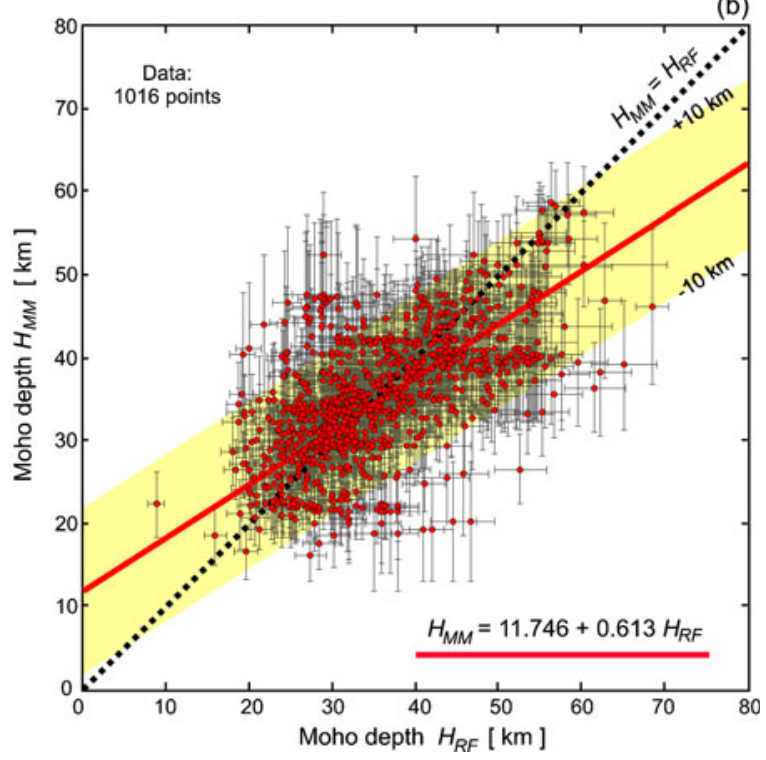

Fig. 3 a A comparison between crustal thicknesses determined from receiver function analysis and their uncertainties. The uncertainty was determined for 393 values of crustal thickness. Thick line shows the linear fit to the data, an area within $\pm 2 \mathrm{~km}$ from the fitted line is marked with the blue band which contains about $85 \%$ of the data. Dotted line shows an envelope of maximum uncertainty. b A comparison between the Moho depth $H_{\mathrm{MM}}$ from the Moho depth map of the European Plate (Grad et al. 2009) and the Moho depth from receiver function analysis $H_{\mathrm{RF}}$. For receiver function, the Moho depth was obtained from crustal thickness, taking topography into account. Both $H_{\mathrm{MM}}$ and $H_{\mathrm{RF}}$ are in kilometers below sea level. The total number of 1,016 receiver function data points and the corresponding depths taken from the map are plotted together with error bars

were consistent. The uncertainties are different for different seismic techniques and can be different even for the same technique in different experiments and areas. The lowest uncertainty is in the order of 5\% for new, modern, good-quality seismic refraction profiles, available in digital form (e.g., models obtained by ray tracing modeling). This gives about $\pm 2 \mathrm{~km}$ uncertainty for 40-km-thick crust. Older, reinterpreted, compiled, and/or manually digitized profiles have lower quality, with uncertainty in the order $6-8 \%$. The highest uncertainty (about 20\%) was attributed to results obtained from surface waves and gravity modeling. For all the data points used to construct the Moho depth map (for the same latitude $\phi$ and longitude $\lambda$ ), corresponding values of uncertainties (in kilometers) were attributed. The map of the Moho depth uncertainty was constructed using the same projection, transformation, filtering, etc., as the Moho depth map (Grad et al. 2009; in digital form also at WWW pages). The uncertainty of the Moho depths $H_{\mathrm{MM}}$ ranges from \pm 2 to $\pm 10 \mathrm{~km}$. The lowest uncertainty in the order of $\pm 2-4 \mathrm{~km}$ is associated with the continental part of Western, Central, and Northern Europe. Similar values are associated with the oceanic crust. However, since the oceanic Moho depth is about $10-15 \mathrm{~km}$, the relative uncertainty is larger. The largest uncertainty is observed for Greenland and Africa-Arabia transition, where the resolution of the present map is the lowest.

The data sets used in the construction of the Moho depth map for the European Plate (Grad et al. 2009) were dominated by results from seismic profiles and their compilations (local and regional maps). Thus, the data density was relatively higher than for individual stations used for the Moho depth determination from receiver function analysis. The Moho map for the British Isles and surrounding areas constructed from many seismic profiles and gravity modeling (Kelly et al. 2007) had much larger weight than limited number of RF data (Tomlinson et al. 2006) - their influence on final map is rather small.

What comes to the uncertainties and errors in the Moho depth determinations, we can raise numerous questions, starting from the quality of observations and experimental data, to processing and interpretation methods. Below, we have listed some problems related to the two main structural methods: seismic refraction and receiver function. It is not easy to make precise quantitative evaluations without real data, and unfortunately, such evaluations are not common in the original papers and have been published only in some papers. Very often, even basic information about profile is missing, information such as the shot and receiver locations, examples of recorded data, and accuracy of the timing procedure.

- Although both seismic refraction and receiver function methods can reveal the structure of the Earth's crust and uppermost mantle, their 

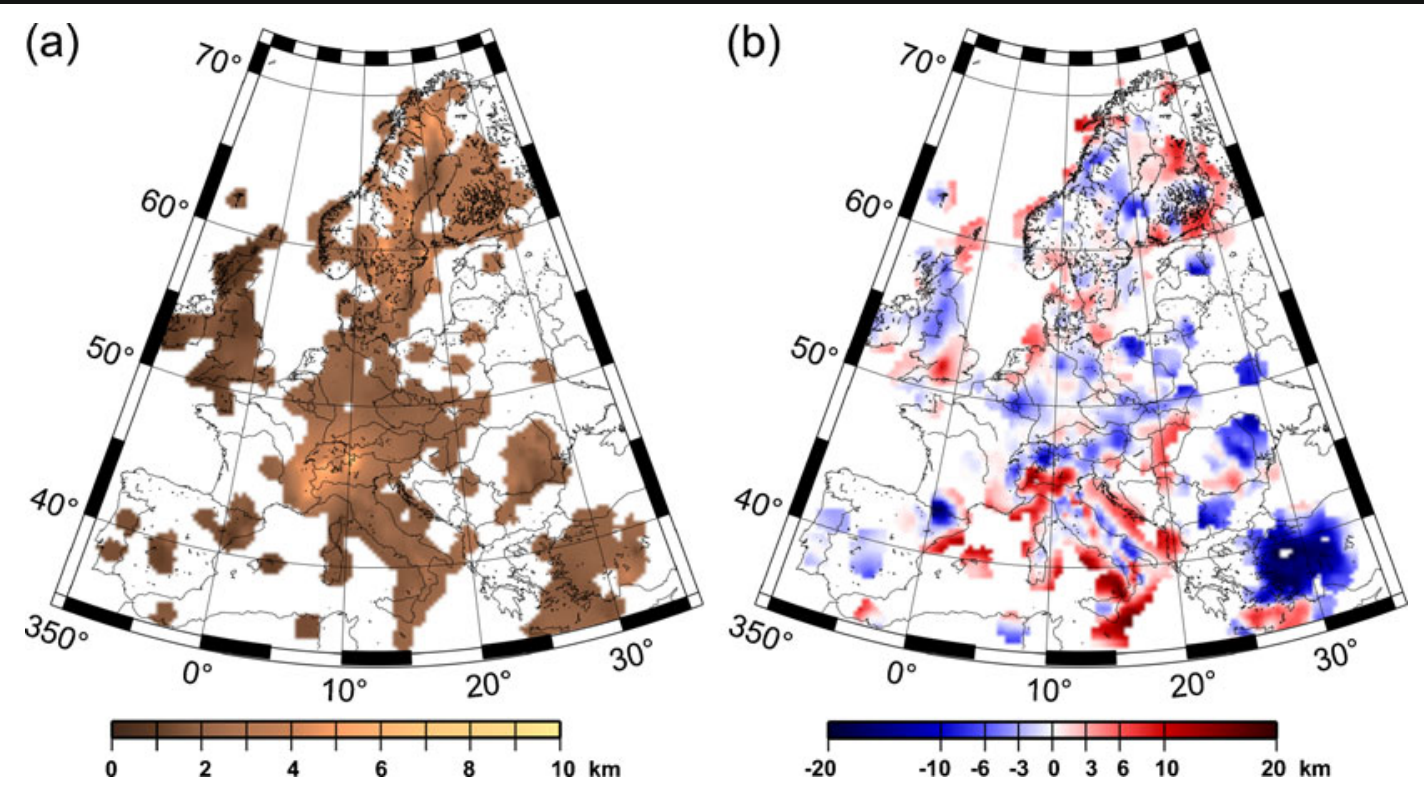

Fig. 4 The Moho depth for the continental part of the Central and the Western Europe. a Uncertainty of the crustal thicknesses determined from receiver function analysis. b Difference of the Moho depths $H_{\mathrm{RF}}-H_{\mathrm{MM}}$

underlying principles are quite different. In seismic refraction method, we investigate the structures using mostly $P$ waves (refracted and reflected) going down into the crust. In receiver function method, we investigate the structures using upgoing $S$ waves from teleseismic events ( $P$-to- $S$ converted at the Moho and other discontinuities). This is the first source of deviations between the methods. On the other hand, this gives a chance to create a common, integrated $P$ and $S$-wave velocity model for the same area. For example, known $P$-wave velocity model from a refraction study can be used as a good starting point for $S$-wave modeling with receiver function method.

- Different techniques are applied in the interpretation of RF. In the first step of RF processing, original components of seismogram $(Z, N, E)$ are rotated into vertical, radial, and tangential $(Z, R$, $T)$ components or into ray-parameter coordinate system $(L, Q, T)$ which is useful to separate different wave types $P, S V$, and $S H$ (Vinnik 1977; Geissler et al. 2008). In the estimation of the Moho depth, the delay time of $P$-to- $S$ converted waves is compared to the direct $P$-wave (e.g., Langston 1979; Ammon 1991; Cassidy 1992). To investigate the 1-D $S$-wave velocity structure beneath the station the time-domain inversion methods are applied to the radial receiver function: linear, semi-linear, stochastic inversionsee, e.g., Ammon et al. (1990) and Hetényi and Bus (2007). However, the result of inversion depends on the starting model, in particular for noisy data. In order to receive independent results, we can run the inversion with many different starting models and then stack the results to calculate one mean model of the structure (e.g., Wilde-Piórko et al. 2002). Forward modeling using trial-and-error method may find a simple model which could well explain the observed receiver functions. In forward modeling, a generalization and simplification of the models could complement and correct the results of inversion.

- In RF technique, the Moho depth is usually projected beneath the station. However, the observed converted and reverberated phases $P S$, $P s P m P+P p S m P$ and $P s S m P(P, p$-longitudal, $S$, $s$-shear waves, $m$-reflection from the Moho), come from the wide area around the station, which at the Moho is from a few tens up to a hundred kilometers in diameter. In seismic refraction method, the system of reciprocal travel times permits for determination of dipping boundaries along profiles. For 2-D refraction profiles, however, modeling does not take into account out-ofplane refractions and reflections, which could 
occur in structurally complex regions. In such case, 3-D approach should be used.

- In the past decade, the RF method by Zhu and Kanamori (2000) for simultaneous determination of the Moho depth and Poisson's ratio in the crust has become very popular. An average Poisson's ratio $\sigma$ in the crust and the Moho depth $H$ are estimated in a grid search over the $\sigma-H$ space, and the $(\sigma, H)$ pair which is in the closest agreement with the observed converted and reverberated phases is determined. This method was found to be very sensitive to the average Poisson's ratio in the crust, but it works only for sharp Moho (with large contrast of elastic parameters), when clear Moho conversions and their associated multiples are observed (e.g., Kumar et al. 2007). Weak point of this method is the assumption of an average $V_{\mathrm{P}}$ velocity in the crust. As result, the average Poisson's ratio $\sigma$ in the crust (or $V_{\mathrm{P}} / V_{\mathrm{S}}$ ratio) may not be adequate and sufficient for the whole crust. For example, in the East European craton $V_{\mathrm{P}} / V_{\mathrm{S}}$ ratio is about $1.67,1.73$, and 1.77 in the upper, middle, and lower crusts, respectively. This means that the $S$-wave velocity in the crust is not much differentiated and the relative contrast of $V_{\mathrm{S}}$ velocity at the Moho is larger than that for $P$ waves.

- The accuracy of the seismic velocity structure determined using teleseismic receiver functions is a complex problem since it strongly depends on many factors. Usually many tens or hundreds good-quality seismograms of teleseismic events are recorded by a single permanent broadband station (e.g., Piana Agostinetti and Amato 2009; Geissler et al. 2008). However, even a large number of seismograms do not guarantee a good azimuthal coverage (e.g., Radjaee et al. 2010). This is particularly important when the structure beneath the station could not be approximated by a 1-D model, i.e., in the case of dipping layers or anisotropy. These effects are usually visible in the azimuthal distribution of tangential components of RF. For temporary passive experiments, this is even bigger problem, due to the limited number of events. Usually during 1 year of a campaign, only about few tens of good quality records, with magnitude $M \geq 5.5$, are collected (Kozlovskaya et al. 2008; Gregersen et al. 2006; Wilde-Piórko et al. 2008). Stacking of RF results is smoothed as that covers a wide range of azimuths and distances.

- The frequencies of $P$ waves recorded in seismic refraction studies are in the range of $5-10 \mathrm{~Hz}$, while stacked receiver functions have pulses with smaller frequencies, about $1-2 \mathrm{~Hz}$. Also, filtration of the receiver functions influences their quality and frequency (low-pass Gaussian filtration with parameter of 2-4, influence of water-level parameters). Because of that, the frequency resolution is better for the refraction method.

- For both seismic refraction and receiver function methods, crustal anisotropy is a difficult problem to solve. To detect anisotropy in a seismic refraction studies, a dense system of 3-D recordings is needed. In receiver function, some opportunities give interpretation of transversal component of RF.

- The velocity structure and crustal thickness determined for the same broadband station in different receiver function studies can also differ. This can stem from the use of different data sets (in particular a small number of seismograms) and interpretation techniques. For permanent stations in Bohemian massif, the crustal thicknesses presented in the papers by Wilde-Piórko et al. (2005) and Geissler et al. (2008) differ only by about $\pm 1 \mathrm{~km}$; however, in other regions, differences can reach more than $\pm 5 \mathrm{~km}$, as is the case for Greenland (Dahl-Jensen et al. 2003; Kumar et al. 2007).

- In seismic refraction and wide angle reflection method observed PmP waves are weak for weak contrast at the Moho (gradient Moho zone). At the same time, good quality refracted $P n$ waves still give an opportunity for proper identification and determination of the crust-mantle transition. Ps wave converted at the same gradient Moho transition gives weak receiver function response, which weakens the precision of the Moho depth $H_{R F}$ determination.

The above list of mostly "technical" problems is not exhaustive. In seismic refraction, in seismic tomography, and ray-tracing techniques, the uncertainty has resulted from subjectively picked travel times. Their accuracy increases with increasing quality and amount of data. Both in seismic refraction and receiver function techniques, the results (models of the structure) depend on different model parameterization, different inversion techniques used, etc. As an example, Fig. 5 shows 


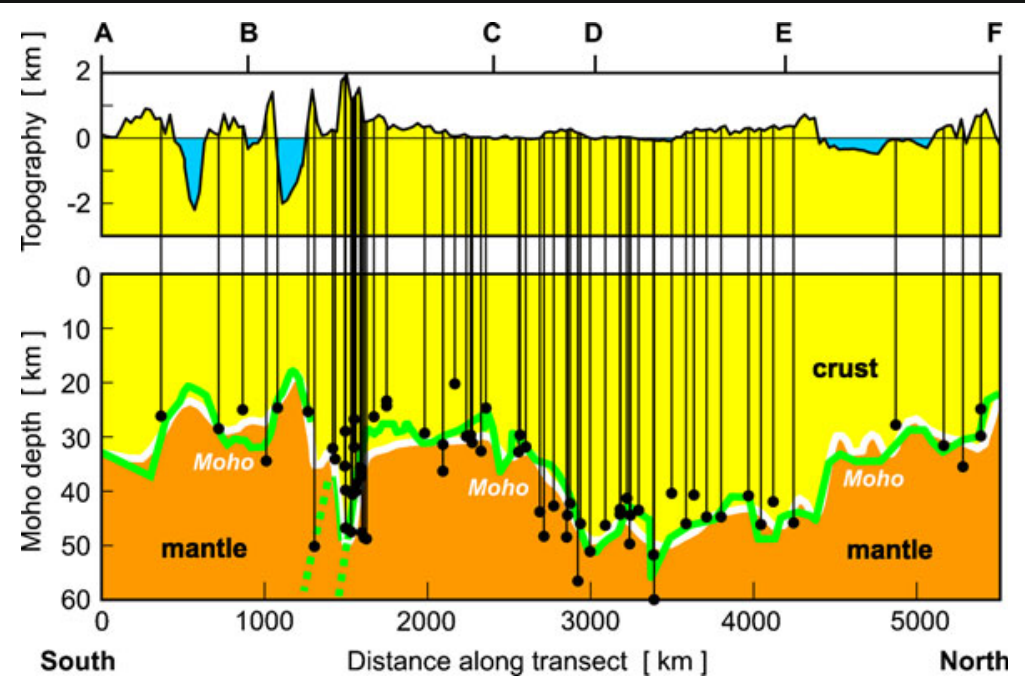

Fig. 5 The comparison of the Moho depth along 5,500-kmlong transect $\mathrm{A}-\mathrm{F}$ at ca. $10-20^{\circ} \mathrm{E}$ longitude (for location, see Fig. 1). For the transect line, the Moho depth from the map is shown by a thick white line (Grad et al. 2009). The Moho depth from refraction profiles is compiled for EGT-South, EUGEMI, EUGENO-S line 1, FENNOLORA, and refraction profiles in Arctic (Ansorge et al. 1992; Neprochnov et al. 2000; Breivik et

comparison of the Moho depth along a 5,500-km-long transect A-F running through the Europe at ca. 10$20^{\circ} \mathrm{E}$ longitude (for location, see Fig. 1). For the transect line, the Moho depth from the map is shown by a thick white line (Grad et al. 2009). The Moho depth from active data is compiled from profiles EGTSouth, EUGEMI, EUGENO-S line 1, FENNOLORA, and refraction profiles in Arctic (Ansorge et al. 1992; Neprochnov et al. 2000; Breivik et al. 2005; Czuba et al. 1999, 2008, 2011) and is shown by thick green line. The changes in the Moho depth from refraction data are sharp and, at distances of about 1,2001,500 km, show "second" Moho in Alps (subducting Moho-dotted green lines in Fig. 5). Both Moho depths ("white" and "green" lines) are consistent; however, the Moho depth from the map is smoother, which results from compilation of 3-D data, as well as smoothing and interpolation. RF data are compiled along a transect within \pm 50 -km-wide corridor (with the exception of two southernmost points which are about 120 and $55 \mathrm{~km}$ from the transect line). Black dots show the Moho depths and vertical lines show positions of stations along transect. In general, RF data "oscillate" around continuous curves, and in this example (67 RF points), any convincing trend is not seen. al. 2005; Czuba et al. 1999, 2008, 2011) and is shown by a thick green line. Thick dotted green lines at distances of about 1,200-1,500 km show "second" Moho in the Alps (subducting Moho). The Moho depths from RF are compiled along A-F transect within \pm 50 -km-wide corridor-black dots show the Moho depth and vertical lines show positions of stations along the transect

\section{Summary and conclusions}

Herein, we have compared the Moho depths from the Moho depth map of the European Plate by Grad et al. (2009) and the Moho depth values obtained with RF methods by several authors. The best coverage of the crustal thickness from RF determinations comes from the continental part of the Western and Central Europe. There is practically no RF data available beneath the ocean and the seas. Based on 393 values of crustal thickness, we have determined linear relation (1) of the Moho depths $H_{\mathrm{RF}}$ and their error estimates (Fig. 3a). Most of the error estimates seem rather optimistic, when compared to the total range of the values. Linear fit (2) between $H_{\mathrm{RF}}$ and $H_{\mathrm{MM}}$ (Fig. 3b) shows that the receiver function method gives shallower Moho when the Moho depth is smaller than $30 \mathrm{~km}$ and deeper Moho (than other methods) when the Moho depth is more than $40 \mathrm{~km}$. It should be noted that in some cases for inversion of $R F$, instead of regional crustal velocity structure, global velocity models (e.g., iasp91, Kennett and Engdahl 1991), or other reference models with global crustal thickness of about $35 \mathrm{~km}$ are used (see for example Sodoudi et al. 2009; Hetényi and Bus 2007; Paul et al. 2006). This could be the main reason for 
the observed discrepancy between the Moho depths $H_{\mathrm{MM}}$ and $H_{\mathrm{RF}}$. Distribution of the Moho depth values based on RF (in the range of 10-70 km) is clearly wider than the distribution of the Moho depths from other seismic methods (in the range of $15-55 \mathrm{~km}$ ) for the study area.

Acknowledgments The authors wish to thank Finnish Academy of Science and Letters, Väisälä Foundation for financial support. Geographic data handling and plotting was done with GMT software by P. Wessel and W.H.F Smith. The linear data fitting was done with program Glove from New Planet Software. The authors are grateful to four anonymous reviewers for helpful comments and raising numerous questions that were not answered in the first version of manuscript. The authors are grateful to Dr. Emilia Koivisto for improving the English language.

Open Access This article is distributed under the terms of the Creative Commons Attribution Noncommercial License which permits any noncommercial use, distribution, and reproduction in any medium, provided the original author(s) and source are credited.

\section{References}

Al-Damegh K, Sandvol E, Barazangi M (2005) Crustal structure of the Arabian plate: new constraints from the analysis of teleseismic receiver functions. Earth Planet Sc Lett 231:177-196

Aleshin IM, Kosarev GL, Riznichenko OYu, Sanina IA (2006) Crustal velocity structure under the RUKSA seismic array (Karelia, Russia). Russ J Earth Sci 8:ES1003. doi:10.2205/ 2006ES000194

Amante C, Eakins BW (2009) ETOPO1 1 Arc-Minute Global Relief Model: procedures, data sources and analysis. NOAA Technical Memorandum NESDIS NGDC-24, 19pp

Ammon CJ (1991) The isolation of receiver effects from teleseismic P waveforms. Bull Seism Soc Am 81:2504-2510

Ammon CJ, Randall GE, Zandt G (1990) On the nonuniqueness of receiver function inversions. J Geophys Res 95:15303-15318

Angus DA, Wilson DC, Sandvol E, Ni JF (2006) Lithospheric structure of the Arabian and Eurasian collision zone in eastern Turkey from S-wave receiver functions. Geophys J Int 166:1335-1346

Ansorge J, Blundell D, Mueller St (1992) Europe's lithosphereseismic structure. In: Blundell DJ, Freeman R, Mueller St (ed) A continent revealed - the European geotraverse. Cambridge University Press, Cambridge, pp 33-69

Bertrand E, Deschamps A (2000) Lithospheric structure of the southern French Alps inferred from broadband analysis. Phys Earth Planet Inter 122:79-102

Breivik AJ, Mjelde R, Grogan P, Shimamura H, Murai Y, Nishimura Y (2005) Caledonide development offshoreonshore Svalbard based on ocean bottom seismometer, conventional seismic and potential data. Tectonophysics 401:79-117

Cassidy JF (1992) Numerical experiments in broadband receiver function analysis. Bull Seism Soc Am 82:1453-1474

Czuba W, Grad M, Guterch A (1999) Crustal structure of northwestern Spitsbergen from DSS measurements. Polish Polar Res 20(2):131-148

Czuba W, Grad M, Guterch A, Majdański M, Malinowski M, Mjelde R, Moskalik M, Środa P, Wilde-Piórko M, Nishimura Y (2008) Seismic crustal structure along the deep transect Horsted'05, Svalbard. Polish Polar Res 29 (3):279-290

Czuba W, Grad M, Mjelde R, Guterch A, Libak A, Krüger F, Murai Y, Schweitzer J, the IPY Project Group (2011) Continent-ocean-transition across a trans-tensional margin segment: off Bear Island, Barents Sea. Geophys J Int 184:541-554. doi:10.1111/j.1365-46X.2010.04873.x

Dahl-Jensen T, Larsen TB, Woelbern I, Bach T, Hanka W, Kind R, Gregersen S, Mosegaard K, Voss P, Gudmundsson O (2003) Depth to Moho in Greenland: receiver-function analysis suggests two Proterozoic blocks in Greenland. Earth Planet Sci Lett 205:379-393

Di Leo J, Bastow ID, Helffrich G (2009) Nature of the Moho beneath the Scottish Highlands from a receiver function perspective. Tectonophysics 479:214-222. doi:10.1016/j. tecto.2009.08.014

Diehl T, Ritter JRR, the CALIXTO Group (2005) The crustal structure beneath SE Romania from teleseismic receiver functions. Geophys J Int 163:238-251. doi:10.1111/ j.1365-246X.2005.02715.x

Doloei J, Roberts R (2003) Crust and uppermost mantle structure of Tehran region from analysis of teleseismic Pwaveform receiver functions. Tectonophysics 364:115-133

Foulger GR, Anderson DL (2005) A cool model for the Iceland hotspot. J Volcan Geotherm Res 141:1-22

Geissler WH, Kind R, Yuan X (2008) Upper mantle and lithospheric heterogeneities in central and eastern Europe as observed by teleseismic receiver functions. Geophys J Int 174:351-376. doi:10.1111/j.1365-246X.2008.03767.x

Grad M, Tiira T, ESC Working Group (2009) The Moho depth map of the European Plate. Geophys J Int 176:279-292. doi:10.1111/j.1365-246X.2008.03919.x

Gregersen S, Voss P, Shomali ZH, Grad M, Roberts RG, TOR Working Group (2006) Physical differences in the deep lithosphere of Northern and Central Europe. Geol Soc Lond Mem 32:313-322

Gudmundsson Ó (2003) The dense root of the Iceland crust. Earth Planet Sci Lett 206:427-440

Harland KE, White RS, Soosalu H (2009) Crustal structure beneath the Faroe Islands from teleseismic receiver functions. Geophys J Int 177:115-124. doi:10.1111/ j.1365-246X.2008.04018.x

Hetényi G, Bus Z (2007) Shear wave velocity and crustal thickness in the Pannonian Basin from receiver function inversions at four permanent stations in Hungary. J Seismol 11:405-414. doi:10.1007/s10950-007-9060-4

Julià J, Mejía J (2004) Thickness and Vp/Vs Ratio Variation in the Iberian Crust. Geophys J Int 156:59-72. doi:10.1111/ j.1365-246X.2004.02127.x

Kelly A, England RW, Maguire PKH (2007) A crustal seismic velocity model for the UK, Ireland and surrounding seas. 
Geophys J Int 171:1172-1184. doi:10.1111/j.1365246X.2007.03569.x

Kennett BLN, Engdahl ER (1991) Traveltimes for global earthquake locations and phase identifications. Geophys J Int 105:429-465

Kortström J, Wilde-Piórko M, Tiira T, Komminaho K (2006) Receiver function analysis of the broad band data of Finnish Seismograph Network. Proceedings of the 37th Nordic Seminar on Detection Seismology, University of Iceland, Abstracts

Kozlovskaya E, Kosarev G, Aleshin I, Riznichenko O, Sanina I (2008) Structure and composition of the crust and upper mantle of the Archean-Proterozoic boundary in the Fennoscandian shield obtained by joint inversion of receiver function and surface wave phase velocity of recording of the SVEKALAPKO array. Geophys J Int 175:135-152. doi:10.1111/j.1365-246X.2008.03876.x

Kumar P, Kind R, Priestley K, Dahl-Jensen T (2007) Crustal structure of Iceland and Greenland from receiver function studies. J Geophys Res 112:B03301. doi:10.1029/ 2005JB003991

Kummerow J, Kind R, Oncken O, Giese P, Ryberga T, Wylegalla K, Scherbaum F, TRANSALP Working Group (2004) A natural and controlled source seismic profile through the Eastern Alps: TRANSALP. Earth Planet Sci Lett 225:115-129

Landes M, Ritter JRR, O'Reilly BM, Readman PW, Do VC (2006) A N-S receiver function profile across the Variscides and Caledonides in SW Ireland. Geophys J Int 166:814-824. doi:10.1111/j.1365-246X.2006.03052.x

Langston CA (1979) Structure under Mount Rainier, Washington, inferred from teleseismic body waves. J Geophys Res $84: 4749-4762$

Li X, Bock G, Vafidis A, Kind R, Harjes HP, Hanka W, Wylegalla K, van der Meijde M, Yuan X (2003) Receiver function study of the Hellenic subduction zone: imaging crustal thickness variations and the oceanic Moho of the descending African lithosphere. Geophys J Int 155:733-748

Lombardi D, Braunmiller J, Kissling E, Giardini D (2008) Moho depth and Poisson's ratio in the Western-Central Alps from receiver functions. Geophys J Int 173:249-264. doi:10.1111/j.1365-246X.2007.03706.X

Marone F, van der Meijde M, van der Lee S, Giardini D (2003) Joint inversion of local, regional and teleseismic data for crustal thickness in the Eurasia-Africa plate boundary region. Geophys J Int 154:499-514

Meissner R (1986) The continental crust - a geophysical approach. Int Geophys Ser Acad Press Inc Orlando $34: 1-426$

Mele G, Sandvol E (2003) Deep crustal roots beneath the northern Apennines inferred from teleseismic receiver functions. Earth Planet Sci Lett 211:69-78

Mele G, Sandvol E, Cavinato GP (2006) Evidence of crustal thickening beneath the central Apennines (Italy) from teleseismic receiver functions. Earth Planet Sci Lett 249:425-435

Mohorovičić A (1910) Potres od 8.X.1909. Godišnje izvješće zagrebačkog meteorološkog opservatorija 9(4/1), 1-56 (and English translation in 1992: Earthquake of 8 October 1909). Geofizika 9:3-55
Mohsen A, Hofstetter R, Bock G, Kind R, Weber M, Wylegalla $\mathrm{K}$, Rümpker G, the DESERT Group (2005) A receiver function study across the Dead Sea transform. Geophys J Int 160:948-960

Neprochnov YuP, Semenov GA, Sharov NV, Yliniemi J, Komminaho K, Luosto U, Heikkinen P (2000) Comparison of the crustal structures of the Barents Sea and the Baltic Shield from seismic data. Tectonophysics 321:429-447

Olsson S, Roberts RG, Böðvarsson R (2008) Moho depth variation in the Baltic Shield from analysis of converted waves. GFF 130(3):113-122, Stockholm ISSN 1103-5897

Ottemöller L, Midzi V (2003) The crustal structure of Norway from inversion of teleseismic receiver functions. J Seismol $7: 35-48$

Paul A, Kaviani A, Hatzfeld D, Vergne J (2006) Seismological evidence for crustal-scale thrusting in the Zagros mountain belt (Iran). Geophys J Int 166:227-237

Piana Agostinetti NP, Amato A (2009) Moho depth and Vp/Vs ratio in peninsular Italy from teleseismic receiver functions. $\mathrm{J}$ Geophys Res 114:B06303. doi:10.1029/2008JB005899

Radjaee A, Rham D, Mokhtari M, Tatar M, Priestley K, Hatzfeld D (2010) Variation of Moho depth in the central part of the Alborz Mountains, northern Iran. Geophys J Int 181:173-184. doi:10.1111/j.1365-246X.2010.04518.x

Saunders P, Priestley K, Taymaz T (1998) Variations in the crustal structure beneath western Turkey. Geophys J Int 134:373-389

Silveira G, Vinnik L, Stutzmann E, Farra V, Kiselev S, Morais I (2010) Stratification of the Earth beneath the Azores from $\mathrm{P}$ and $\mathrm{S}$ receiver functions. Earth Planet Sci Lett. doi:10.1016/j.epsl.2010.08.021

Smith WHF, Wessel P (1990) Gridding with continuous curvature splines in tension. Geophysics 55(3):293-305

Sodoudi F, Yuan X, Kind R, Heit B, Sadidkhouy A (2009) Evidence for a missing crustal root and a thin lithosphere beneath the Central Alborz by receiver function studies. Geophys J Int 177:733-742. doi:10.1111/j.1365-246X.2009.04115.x

Taghizadeh-Farahmand F, Sodoudi F, Afsari N, Ghassemi MR (2010) Lithospheric structure of NW Iran from P and S receiver functions. J Seismol 14:823-836. doi:10.1007/ s10950-010-9199-2

Tezel T, Shibutani T, Kaypak B (2010) Crustal structure variation in western Turkey inferred from the receiver function analysis. Tectonophysics 492:240-252. doi:10.1016/j.tecto.2010.06.006

Tomlinson JP, Denton P, Maguire PKH, Booth DC (2006) Analysis of the crustal velocity structure of the British Isles using teleseismic receiver functions. Geophys J Int 167:223-237. doi:10.1111/j.1365-246X.2006.03044.x

van der Meijde M, van der Lee S, Giardini D (2003) Crustal structure beneath broad-band seismic stations in the Mediterranean region. Geophys J Int 152:729-739

Vinnik LP (1977) Detection of waves converted from P do SV in the mantle. Phys Earth Planet Inter 15:39-45

Weber M, Abu-Ayyash K, Abueladas A, Agnon A, Al-Amoush H, Babeyko A, Bartov Y, Baumann M, Ben-Avraham Z, Bock G, Bribach J, El-Kelani R, Förster A, Förster H-J, Frieslander U, Garfunkel Z, Grunewald S, Götze HJ, Haak V, Haberland Ch, Hassouneh M, Helwig S, Hofstetter A, 
Jäckel K-H, Kesten D, Kind R, Maercklin N, Mechie J, Mohsen A, Neubauer FM, Oberhänsli R, Qabbani I, Ritter O, Rümpker G, Rybakov M, Ryberg T, Scherbaum F, Schmidt J, Schulze A, Sobolev S, Stiller M, Thoss H, Weckmann U, Wylegalla K (2004) The crustal structure of the Dead Sea transform. Geophys J Int 156(3):655-681

Wessel P, Smith WHF (1991) Free software helps map and display data. EOS, Trans AGU 72(41):445-446

Wessel P, Smith WHF (1998) New, improved version of Generic Mapping Tools released. EOS, Trans AGU 79(47):579

Wilde-Piórko M, Grad M, TOR Working Group (2002) Crustal structure variation from the Precambrian to Palaeozoic platforms in Europe imaged by the inversion of teleseismic receiver functions - project TOR. Geophys J Int 150:261-270

Wilde-Piórko M, Saul J, Grad M (2005) Differences in the crustal and uppermost mantle structure of the Bohemian Massif from teleseismic receiver functions. Stud Geophys Geod 49:85-107

Wilde-Piórko M, Geissler WH, Plomerová J, Grad M, Babuška V, Brückl E, Cyziene J, Czuba W, England R, Gaczyński E, Gazdova R, Gregersen S, Guterch A, Hanka W, Hegedüs E, Heuer B, Jedlička P, Lazauskiene J, Keller GR, Kind R, Klinge K, Kolinsky P, Komminaho K, Kozlovskaya E, Krüger F, Larsen T, Majdański M, Málek
J, Motuza G, Novotný O, Pietrasiak R, Plenefisch Th, Růžek B, Sliaupa S, Środa P, Świeczak M, Tiira T, Voss P, Wiejacz P (2008) PASSEQ 2006-2008: passive seismic experiment in Trans-European suture zone. Stud Geophys Geod 52:439-448

Wilde-Piórko M, Grad M, Wiejacz P, Schweitzer J (2009) HSPB seismic broadband station in Southern Spitsbergen: first results on crustal and mantle structure from receiver functions and SKS splitting. Polish Polar Res 30(4):301-316

Zhang J, Langston CA (1995) Dipping structure under Dourbes, Belgium, determined by receiver function modeling and inversion. Bull Seism Soc Am 85:254-268

Zhu L, Kanamori H (2000) Moho depth variation in southern California from teleseismic receiver functions. J Geophys Res 105(B2):2969-2980

Zor E, Sandvol E, Gürbüz C, Türkelli N, Seber D, Barazangi M (2003) The crustal structure of the East Anatolian plateau (Turkey) from receiver functions. Geophys Res Lett 30 (24):8044. doi:1029/2003GL018192

Zor E, Özalaybey S, Gürbüz C (2006) The crustal structure of the eastern Marmara region, Turkey by teleseismic receiver functions. Geophys J Int 167:213-222. doi:10.1111/j.1365-246X.2006.03042.x 